\title{
STUDY OF THE KARST PROCESS DYNAMICS IN KHÓZUÈ: CALCAREOUS MASSIF OF Cheringoma Plateau (MozambiQue)
}

\section{Assane Luís Pena ${ }^{1}$, Manuel Jossias Waene ${ }^{1}$, Maria Virginia Alves Martins ${ }^{2,3}$}

1 Universidade Licungo, Extensão da Beira - UNILICUNGO, Faculdade de Ciências e Tecnologia, Departamento de Geociências, Beira, Mozambique

2 Universidade do Estado do Rio de Janeiro - UERJ, Faculdade de Geologia, Departamento de Paleontologia e Estratigrafia. Av. São Francisco Xavier, 524, Maracanã. 20550-013 Rio de Janeiro, RJ, Brazil

3 Universidade de Aveiro, Departamento de Geociências, GeoBioTec, Campus de Santiago, 3810-193, Aveiro, Portugal

* Corresponding AUthor, assanepena@gmail.com

\author{
Received on 09 October 2019 \\ Received in revised form on 13 November 2019 \\ Accepted on 27 November 2019
}

Editor: Anderson Costa, Universidade do Estado do Rio de Janeiro, Brazil

\author{
Citation: \\ Pena, A.P., Waene, M.J., Alves Martins, M.V., 2019. Study of the karst \\ process dynamics in Khózuè: calcareous massif of Cheringoma \\ Plateau (Mozambique). Journal of Sedimentary Environments, 4 (4): \\ 421-433.
}

\begin{abstract}
The present research was developed aiming to study macroscopically the effects of karstification that, over the time, affected significantly the carbonated massif in Khózuè, Cheringoma Plateau (Mozambique). The research was carried out from a field study (collecting samples and photos) for a period of one week, in May of 2017, in Khózuè. During the field work, evidences found in nature were recorded as well as, the mode of occurrence of several structures (caves, dolines and speleothems). The karstification in the study area that occurs in the Cheringoma Formation (from Middle Eocene) was greatly conditioned by fractures which influenced the process and formation of caves and dolines. These structures tended to follow morphological patterns depending on guide fractures
\end{abstract}

\section{Introduction}

Caves exist in many parts of the world and are often sought for a variety of purposes (Gunn, 2004). In general, the man-cave relationship is ancient (Stringer et al., 1979; Grün et al., 1997; Boaz and Ciochon, 2001). Caves are the oldest shelter of man and, given their peculiarity and fascination, they are still visited and used for several motivations (Gillieson and Smith, 1989; Goldie, 1993; Huang et al., 1995). They may occur in karstic environments characterized by irregular terrain formed from the dissolution of soluble rocks such as limestone, dolomite, and gypsum, where can be found also dolines, sinkholes or cenotes, vertical shafts, foibe, disappearing streams, and reappearing springs (Sweeting, 1973; Jennings, 1985; Palmer, 2009; Gabrovšek and Stepišnik, 2011).

Caves and karstic environments have motivated studies on very diverse subjects (e.g. Bogli, 1980; Gams et al., 1993; Vermeulen and Whitten, 1999; Urich, 2002; Batiot et al., orientation allied to their genesis and creating, in certain cases, dolines with a cross morphology. In addition to caves and dolines, karstic activity in the Cheringoma Formation massif also created other structures, especially speleothems, which are not widespread, and also preservation/fossilization of plant remains by mineralization. Chemical weathering chemical weathering, but especially internal geodynamic phenomena transformed the Khózuè massif one karst region with peculiar characteristics.

Keywords: Karstification. Caves. Dolines. Speleothems. Fossilization. Fractures.

2003; Schlüter, 2006; Ford and Williams, 2007; van Beynen, 2011; Benavente et al., 2015; Maldonado et al., 2016; Ojeda et al., 2019).

In Mozambique, there are several caves, such as that of Khózuè region, which are long known and visited. The general aspects of Khózuè's karst were described by the GTK Consortium (2006) as having deep wells, extensive caves, steep canyons and underground rivers.

As the geological studies involving the Khózuè karst are almost inexistent, this work aims to: identify the main karst structures (caves, dolines, speleothems) and other constituent features of this karst; describe the general aspects visible on the karst surface (vegetation, soil, weathering and other phenomena of interest); reconstruct the sequence/evolutionary history of the main caves (caves dolines and shakeholes). 


\section{Study Area}

The Khózuè carbonated massifs, Cheringoma District, Sofala Province (Fig. 1). Cheringoma District is located in the northeast of Sofala Province, bordered to the north by the Marromeu and Caia districts, in the south by the Muanza District, to the west by the Gorongosa and Maringué districts, and to the east by the Indian Ocean.

According to the Ministry of State Administration (Ministério da Administração Estatal, 2014) the climate of the Cheringoma District is tropical wet, displays savanna vegetation, with the central Inhaminga region covering the entire western range along the Rift Valley. It records average values of annual rainfall, ranging from 1000 to $1200 \mathrm{~mm}$. Rain distribution is uneven throughout the year. About 57
RESEARCH PAPER

to $73 \%$ of annual precipitation occurs from December to March and the temperature varies between $13.8^{\circ} \mathrm{C}$ and $34.1^{\circ} \mathrm{C}$, with an annual average around $24.2^{\circ} \mathrm{C}$.

The geology of the region in which Mozambique is located is quite complex (Afonso, 1977; Iliffe et al., 1991; Afonso et al., 1998; DNG, 2006; Schlüter, 2006; Mueller et al., 2016; Mueller and Jokat, 2017; Habermann et al., 2019). Two geological structures mark the study area, Urema Graben - Rift Valley, which develops to the west of the Cheringoma/Inhaminga Plateau and slightly sloping towards the northeast-southwest and the vast Quaternary delta plain and consolidated dune coastlines which are generally orientated parallel to the coast-line (Schlüter, 2006; Steinbruch, 2010; Ministério da Administração Estatal, 2014).

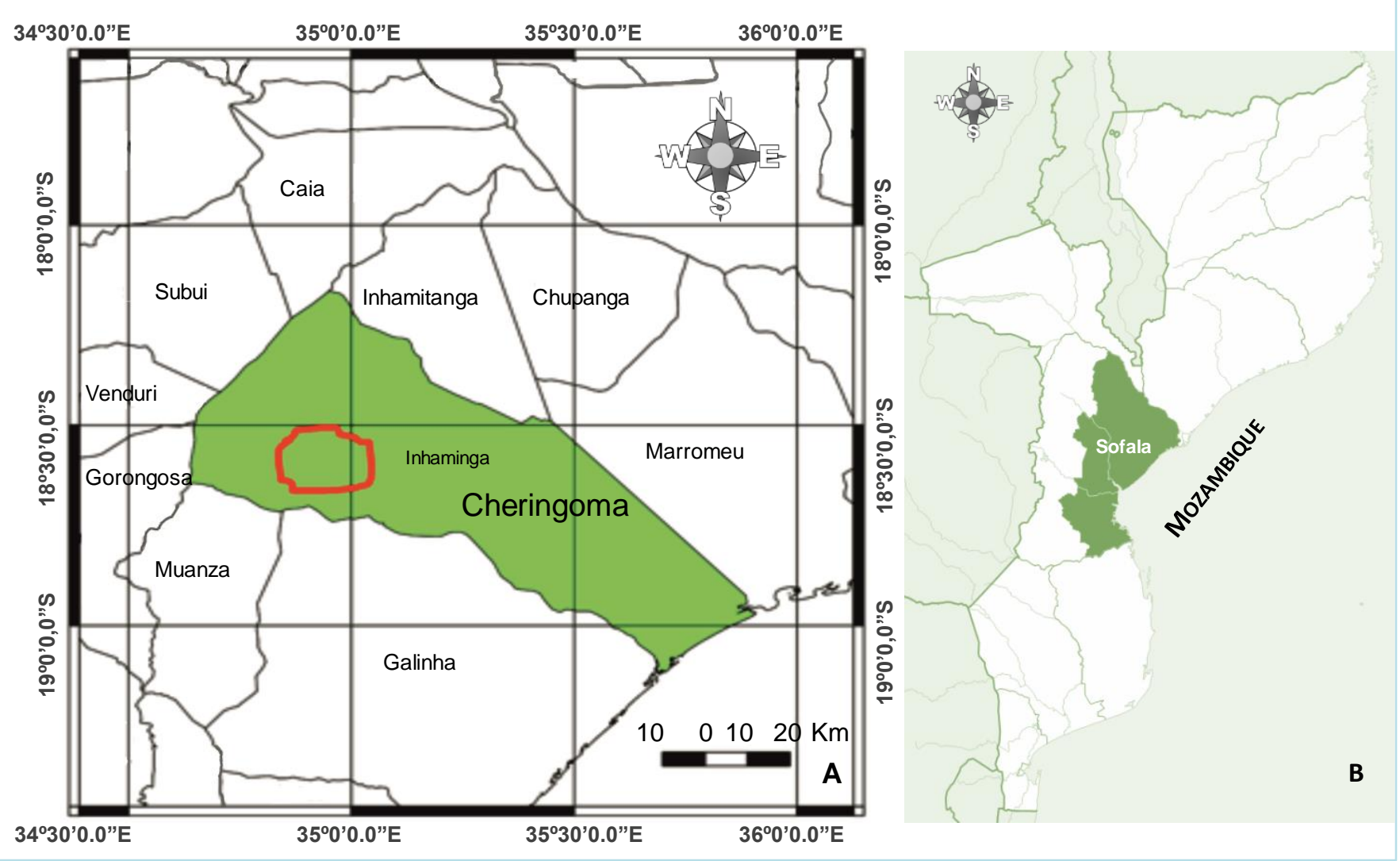

Fig. 1. Study area marked in red, in map A, located in Sofala District, Mozambique (B).

According to the GTK Consortium (2006), the lithostratigraphic units that constitute the Mozambican territory have an Archaic-Cambrian crystalline basement consisting of metamorphic supracrustal paragneisses, granulites and migmatites, orthogneisses and igneous rocks, covered with Phanerozoic rocks of the Karoo Supergroup (oldest) and East African Rift-related sequences (newer). The crystalline basement is divided into three lands (East Gondwana, West Gondwana and South Gondwana), which collided and amalgamated and later dismembered. This break up process, which also represents the first step in the formation of the Mozambique Basin, was marked by extrusive magmatism about 190 M.a. (Nairn et al., 1991; Salman and Abdula, 1995; GTK Consortium, 2006).

So, the main framework of Mozambique Basin development is related to the dismemberment of Gondwana and the development of the East African Rift, from $190 \mathrm{Ma}$. It was a long-lasting period of basin development, with subsidence, continental rise and episodic eustatic sea level fluctuations (Nairn et al., 1991; Salman and Abdula, 1995; Chorowicz, 2005; GTK Consortium, 2006).

Currently, Mozambique Basin occupies an area of about $185,000 \mathrm{~km}^{2}$ on the continent and a considerable marine domain (GTK Consortium, 2006). It has a general 
sedimentary column that can be subdivided into a shallow platform sequence and deeper sequences, restricted to various structures, narrow lines, totaling five major depositional sequences of Cretaceous-Tertiary ages, recognized as delineated by discontinuities or hiatus (Said et al., 2015; GTK Consortium, 2006).

The Karoo Supergroup represents an aborted phase of the continental opening, prior to the continental drift that is associated with the dispersal of the Gondwana Supercontinent, together with the opening of the Indian and South Atlantic oceans and the development of the East African Rift System (Salman and Abdula, 1995; GTK Consortium, 2006; Pereira et al., 2016). This rift system started in the Lower to Middle Cretaceous, accelerated during the Tertiary, which continued to the present day, as evidenced by tectonic activities. The development of the East African Rift System is also associated with the installation of alkaline volcanic rocks, including carbonatites and kimberlites, along the boundaries of the rift, in addition to transgression with continental facies deposits and shallow marine deposits (GTK Consortium, 2006; Senkans et al., 2019).

Cheringoma District is dominated by sedimentary facies. This district includes marine and continental Cretaceous sedimentary deposits of the Mazamba, Cheringoma, Grudja and Seine Formations and sandy and clay sandy alluvials (Schlüter, 2006; Steinbruch, 2010; Administração Estatal, 2014; Said et al., 2015).

The Grudja Formation considered to be dated from Cretaceous to the Paleocene, consists of marine strata of calcarenites or glauconitic calcarenites, siltstones and marl, interspersed, to a lesser extent, with limestones (GTK Consortium, 2006; Mashaba and Altermann, 2015). Considering the discontinuity and lower Paleocene hiatus, this Formation can be divided into two parts, lower and upper one. The Middle-Upper Eocene Cheringoma Formation (Fig. 2) extends into two areas, west of Beira along the Buzi River and north of Beira on the Cheringoma Plateau (DNG, 1968; Schlüter, 2006). It lies discordantly over the aforementioned Grudja Formation (Steinbruch, 2010) and is characterized by shallow, highly energetic marine facies within the photic zone (neritic environment including oxygenated and warm sea waters). To the east and to the deepest areas of the carbonated ramp in the ocean, these limestones become limestone-marl and marllimestone. According to the GTK Consortium (2006), the Cheringoma Formation limestones are oolitic and white, enriched in Nummulites Lamarck, 1801 due to the Upper Eocene floods and has a basal glauconitic and fossil-poor portion. However, the overall unit is rich in fossils: foraminifera such as Nummulites sp., Nummulites atacicus Leymerie, 1846, Discocyclina Gümbel, 1870, bivalves of genus Pecten Müller, 1776, in association with bryozoan, gastropods and calcareous algae (e.g. Lithothamnium Philippi, 1837) and worms (e.g. Polychaeta, Tubulostium Stoliczka, 1868).

\section{Materials and Methods}

This study was conducted in Khózuè, located about 30 $\mathrm{km}$ west of Inhaminga Village (coordinates S18,56359 ${ }^{\circ}$ and E34,87318 ; datum WGS84). This study was supported by field activities and is based on the record of aspects accessible to the direct observation.

To record the observations also were used a Canon digital camera with a resolution of 13 Megapixels, a dipping compass (Blunton mark; for recording the orientations) and a Geographic Positioning System (GPS, Germin Mark; which provided the coordinates of the analyzed locals).

Considering the nature of data, this study is based on inductive generalizations (Lakatos and Marconi, 2003), since a karst is only about 1\% accessible to man (Karmann, 2000).

The observed aspects were used to infer events (Gil, 2008) that occurred in inaccessible karst environments. Thus, the field activities consisted in recognizing the type of structures, their morphologies, mode of occurrence and relationships, as well as their particular characteristics, such as evidences of caves, dolines and shakeholes and their associated fractures (hereinafter treated as guide fractures). Thus, the largest possible number of data were collected. Based on the obtained records and on what was considered to be the initial phase of a cave formation, the evolutionary sequence of the basement formation was tentatively established.

\section{Results and Discussion}

\subsection{Karst aspects}

The result of the karst phenomena that began in the past and still occur today in Khózuè, was the creation of several structures, among them, the most easily recognizable are dolines or sinkholes, shakeholes, uvulas and caves, as well as cenotes, with varying morphologies (Fig. 3). There are also giant sinkholes, sinking streams and speleothems, represented, mainly, in the form of stalactites, stalagmites and pillars.

Inside the Khózuè caves the presence of plants is not significant. However, the vegetation is dense at the entrances and surroundings, where plants tend to develop, competing in thin sediment layers, probably due to the availability of nutrients (Klein and Dutrow, 2012). The residue of limestone dissolution origins a reddish soil, called terra rossa, favorable for vegetation development (Ji et al., 2004)

On the other hand, considering that the caves and/or surroundings also serve as habitat for different animal species (birds, bats, insects, monkeys, etc.), it can be deduced that the nutrients that continue to drive the plant life are not only originated from the residues of limestone dissolution, but also from a cycle of dependence between fauna and flora. This cycle, which can be inferred, prioritizing the presence of fauna, especially the trogloxenes seeking shelter in caves. 
The animal activities from ancient times, have been enriching the soil in organic matter, resulting in vegetation increasing. With the abundance of cave animals and, consequently, vegetation, the presence of other species whose life depends essentially on plants or even other
RESEARCH PAPER

animals such as frugivores, granivores and carnivores also develops. Frugivores and granivores contribute not only with excrements to soil enrichment but also play a very important role in the dispersal of seeds and plant fragments in the study area.

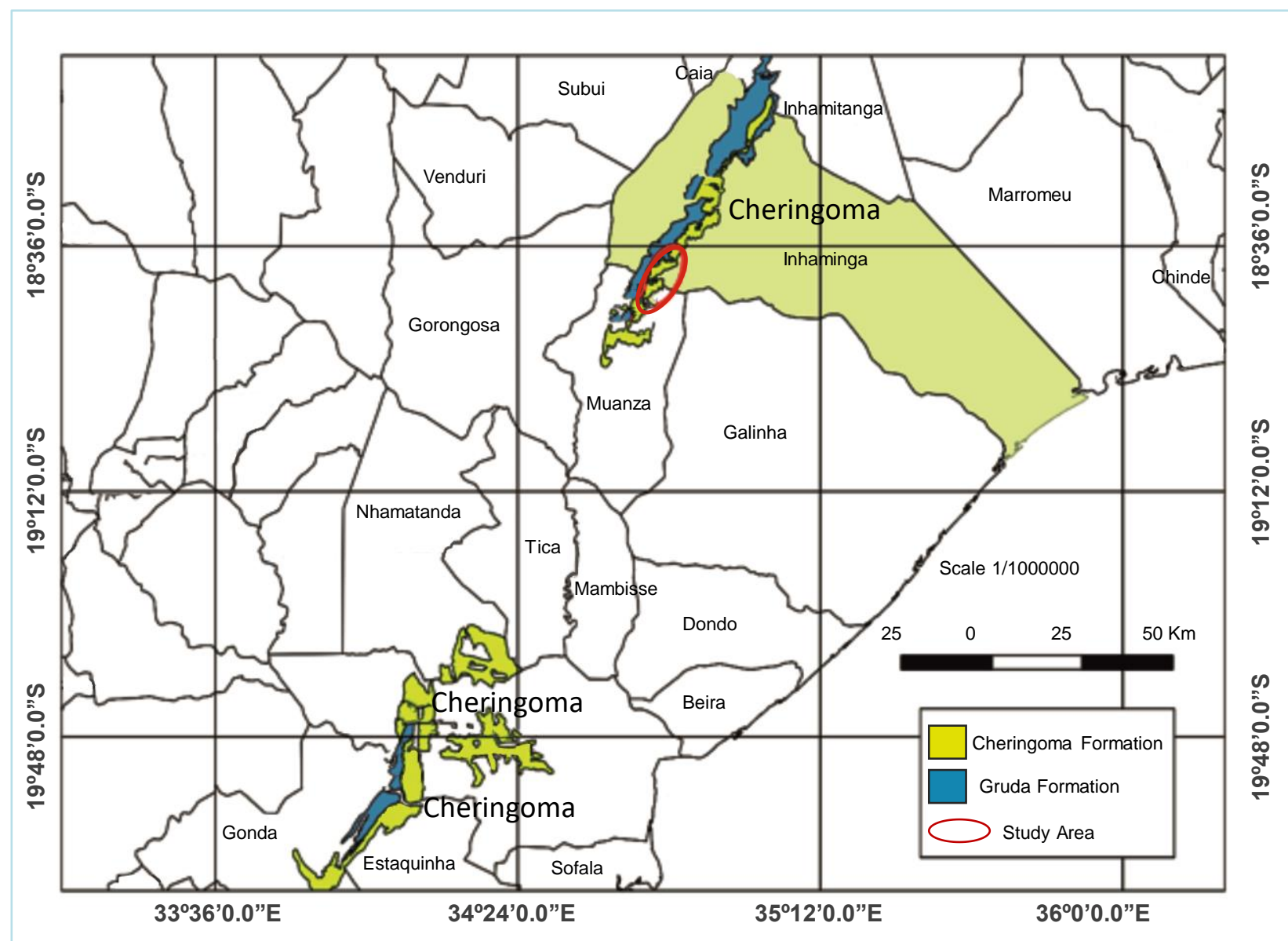

Fig. 2. Map showing the location of Cheringoma Formation, Gruda Formations and the study area (red), in Mozambique. Some administrative regions surrounding the study area are marked.

It can therefore be deduced that the existence of lemon trees (Fig. 4A), one of the most frequent plants in the vegetation around the cave, is related to this process since there is no evidence that this area was inhabited by humans. The continuous interaction of different living beings, associated with the dissolution of limestone, has led to a large supply of organic matter, making the cave and surrounding soil very favorable for plant development, which is now witnessed by the abundance of varied plant species.

Chemical weathering is important in a karst shaping (e.g., Norton and Veselý, 2003; Bleam, 2012; Haldar and Tišljar, 2014). In Khózuè karst, the action of both chemical and physical processes is quite evident, being the plants also an important agent of physical weathering. In the struggle for survival, plants stick their roots in the rock fractures, thus increasing their size or even disintegrating the massif (Fig.
4B). Large trees when struck by wind cause efforts that break the nearby rocks.

The abundance of plants generated conditions for the increase of physical weathering, contributing for rocks breaking by the pressure caused by the root growth in the cracks (Toledo et al., 2000). With the widening of discontinuities, preferred paths are created in which water can flow, enhancing physical and chemical weathering (De Vallejo et al., 2002).

According to Günay et al. (2001), for the development of a karst, the region must receive moderate amount of precipitation, as rocks dissolution only can take place if there is sufficient water. The water that promotes chemical weathering is greatly influenced in terms of quality, by the biosphere action which decreases the $\mathrm{pH}$ of infiltrating waters (Karmann, 2000). 

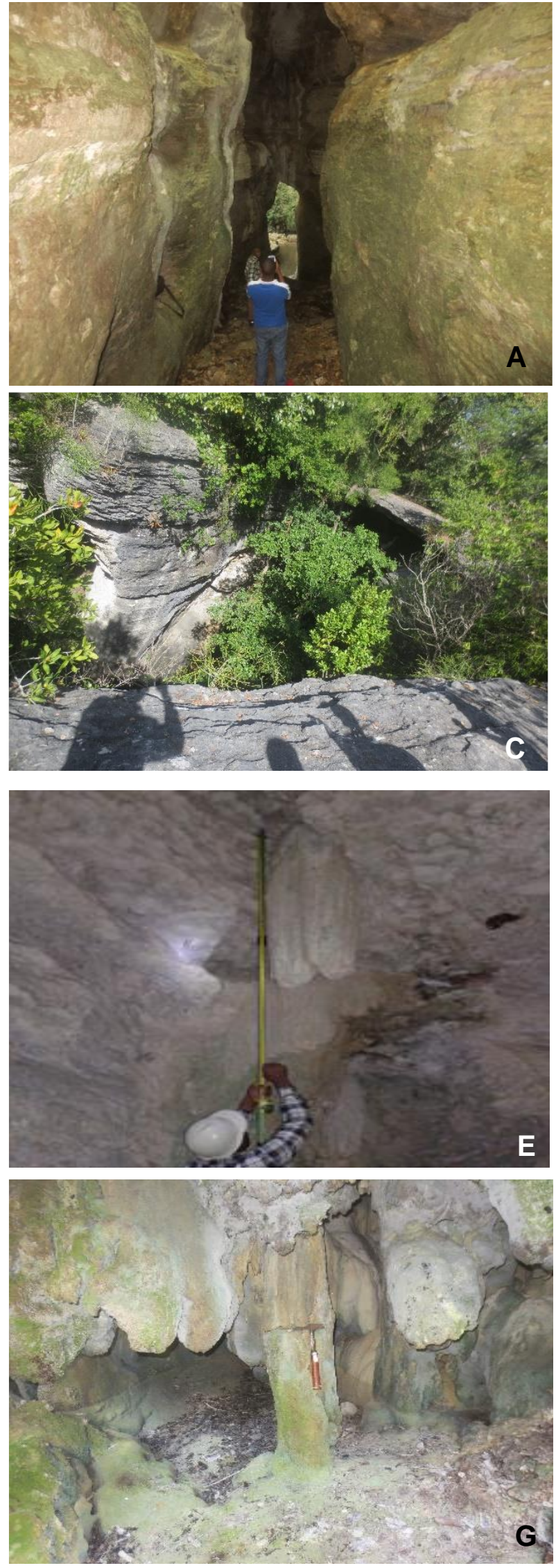

Fig. 3. Main features of Khózuè karst. A - cave; B- doline or sinkholes; C- uvala; D- travertine; E- stalactite; F-stalagmite; G- column; h) cenote.
RESEARCH PAPER
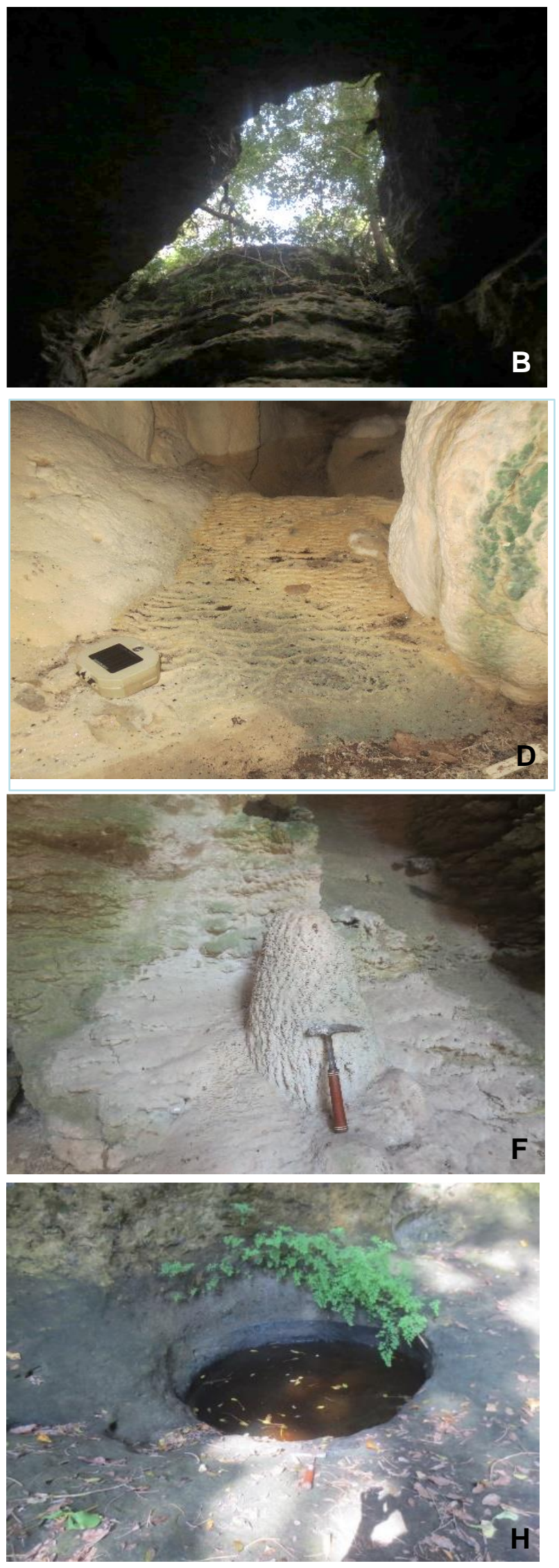

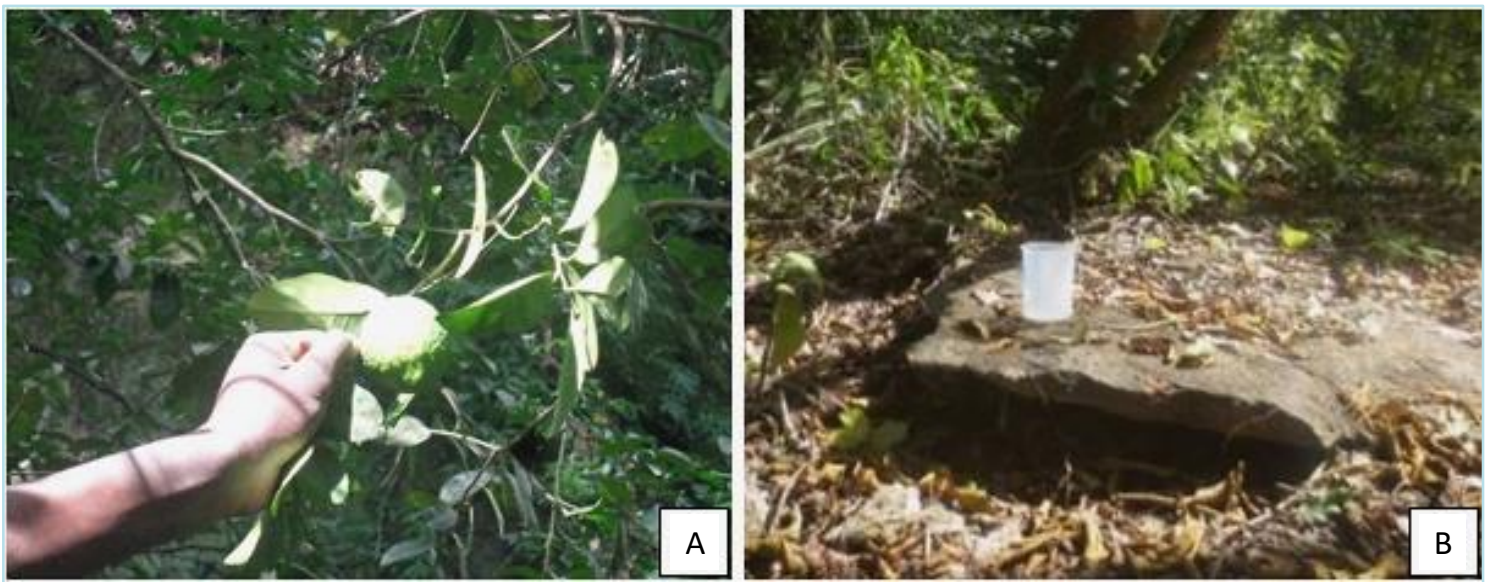

Fig. 4. A. Lemon tree, a very common plant in the woods near the cave. B. The rock block lifted by the strength of a plant roots.

In general, around the roots of the plants, the $\mathrm{pH}$ is even lower, ranging between 2 to 4 , and is maintained while the plant metabolism continues (Läuchli and Grattan, 2012).

Since the climate in the Cheringoma District, where Khózuè is located, is rainy tropical savannah (or tropical wet), the combination of climate effects with biota (also climate dependent) favors chemical weathering, as can be inferred from the effects on the Cheringoma massif. Though occurring simultaneously with the physical process, at present (in a short time view), chemical weathering should prevail over physical weathering, since the combination of the dissolution-erosion has significantly sculpted this formation over the years, resulting in a morphology characterized by caves, dolines, depressions and lumps of the massif at several points.

\subsection{Fossil formation}

According to GTK Consortium (2006), the Cheringoma Formation limestone has marine origin and is rich in fossils, which are also easily observed in the strata or even in hand samples collected in this region. But these observations are not enough to explain the occurrence of preserved plant remains, in different phases of preservation/fossilization, found in a small strip outside the cave (coordinates $\mathrm{S} 18,56018^{\circ}$ and $\mathrm{E} 34,87318^{\circ}$ ).

Preserved biogenic materials are exposed on the surface (without sedimentary cover), leading to the idea that they are being fossilized. In this case, fossilization is being associated with running water, saturated with calcium carbonate (due to carbonate dissolution), that flows through the cave walls and along the limestone formation. This illation is supported by the upward direction of the strip where huge fractured blocks of limestone detached from massif can be observed (Fig. 5). Some of these blocks still exposes a fresh part which indicates that it is dissolving and the solution flows downhill, passing through this small fossiliferous band.

Water charged with calcium and carbonate ions upon contact with the roots, branches, leaves, and other materials found in its way, allows calcite precipitation into small crystals, covering the surface of these materials (Fig. 6) in a process similar to travertine formation (Zhang et al, 2001) and possibly in interaction with biogenic processes (Arnott and Pautard, 1970; Riding, 2000).

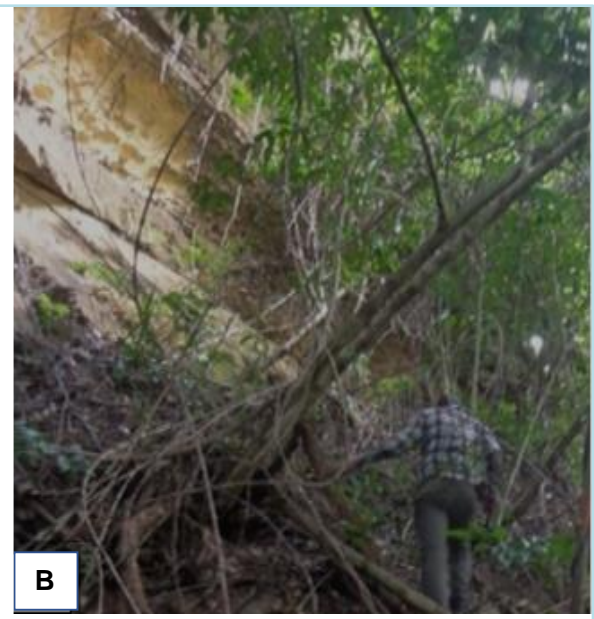

Fig. 5. A. Blocks. B. At the top, the source portion of the calcium carbonate responsible for fossilization. 

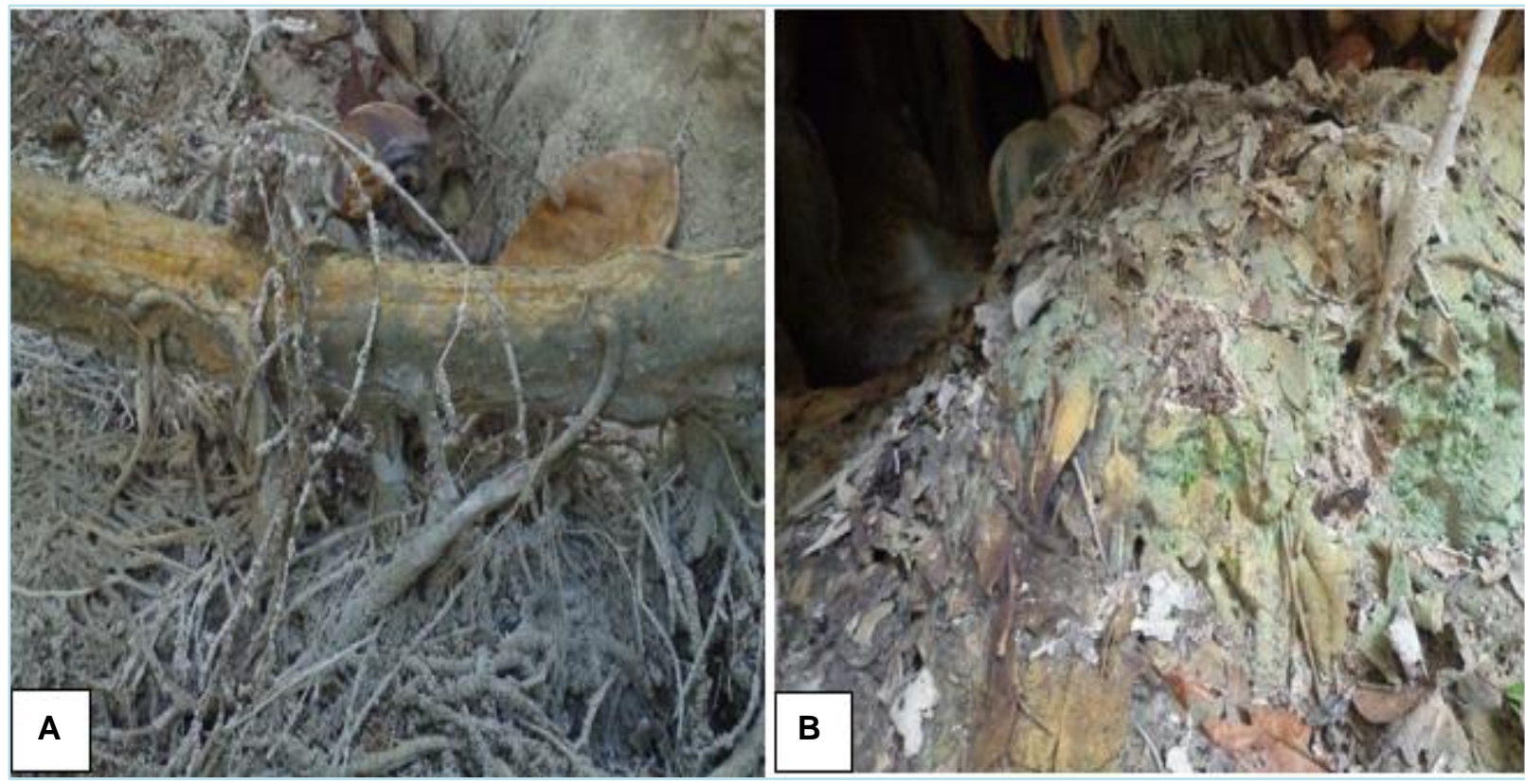

Fig. 6. Different plant features in. A and B preservation/fossilization process of plant remains: A. trunks and roots; B - mostly leaves and trunks.

\subsection{Evolution path of the Khózuè karst}

Any rock that emerges on the Earth's surface is submitted to weathering actions, and may even be completely altered, but this does not necessarily pose weathering as a major threat, since the rock weathering opens the way for the formation of other geological materials, including other rocks (Haldar and Tišljar, 2014). Caves exist because they had a beginning in weathering, they evolve through it, and may even disappear, because of it (Trudgill, 1985; Summerfield, 1991; Gabrovöek, 2002). Though caves have a beginning and an end, they obviously go through several phases (Dreybrodt, 1988; Ford and Williams, 2007). From field observations, it is easy to see that the Khózuè cave is being carved into a layered sedimentary rock. Thus, in order to understand the phases of its evolution, it is necessary to analyze stratigraphic information in interaction with, for instance, tectonic, chemical, physical and hydrogeological aspects revealed therein.

The heterogeneity evident in the strata of the massif, in which the Khózuè Cave is inserted (Fig. 7), influences the weathering, which plays a differential action, since some strata are more susceptible to weathering, and thus more altered and eroded, while others remain more salient, due to their composition and greater resistance to weathering (Fig. 7).

Tectonic activity is one of the most determining factors in speleogenesis and may lead to rock fracturing (Audra and Palmer, 2011). This process is an intrinsic feature of limestone (Barros-Galvis et al., 2015; Su et al., 2017). These rocks can be extremely fissured, which allows rapid infiltration of water (Audra and Palmer, 2011). The
Cheringoma Formation massif in Khózuè has two families of fractures, which may have greater lateral and vertical continuity (Fig. 8). These fractures, in addition to being considered characteristic of the limestone nature, may also have resulted from intense tectonic activity in the region, as Khózuè related to the development of the East African Rift System.

The East African grand rift systems are extended from Red Sea at north to Zambezi at south (Salman and Abdula, 1995; Chorowicz, 2005; GTK Consortium, 2006). This rift, may have been started in the Lower to Middle Cretaceous and accelerated during the Tertiary and continues to nowadays, which is indicated by tectonic activity in the affected areas (GTK Consortium, 2006). Though the fractures above mentioned are not easily observed due to the karst irregularities, as well as the presence of sediment and vegetal remains, they have long lateral and vertical extension and their orientations can be obtained observing the interior of cave walls and ceilings (Figs. 8, 9). Based on these observations, it was possible to idealize the model of occurrence of these fractures which are oriented in the Southeast-Northwest and Southwest-Northeast directions (Fig. 8A).

The fractures may have constituted preferential paths of water percolating from Khózuè caves and have served as a corridor for water rich in carbon dioxide or sulfur that flooded through the vadose zone, favoring the action of chemical processes. Over time, dissolution will lead to empty spaces in the saturated zone. In this way, it can be inferred that, in the Cheringoma Formation massif, the chemical action of water over time, created small cavities from the 
deepest areas of the main fractures (hereafter mentioned as guide fractures).

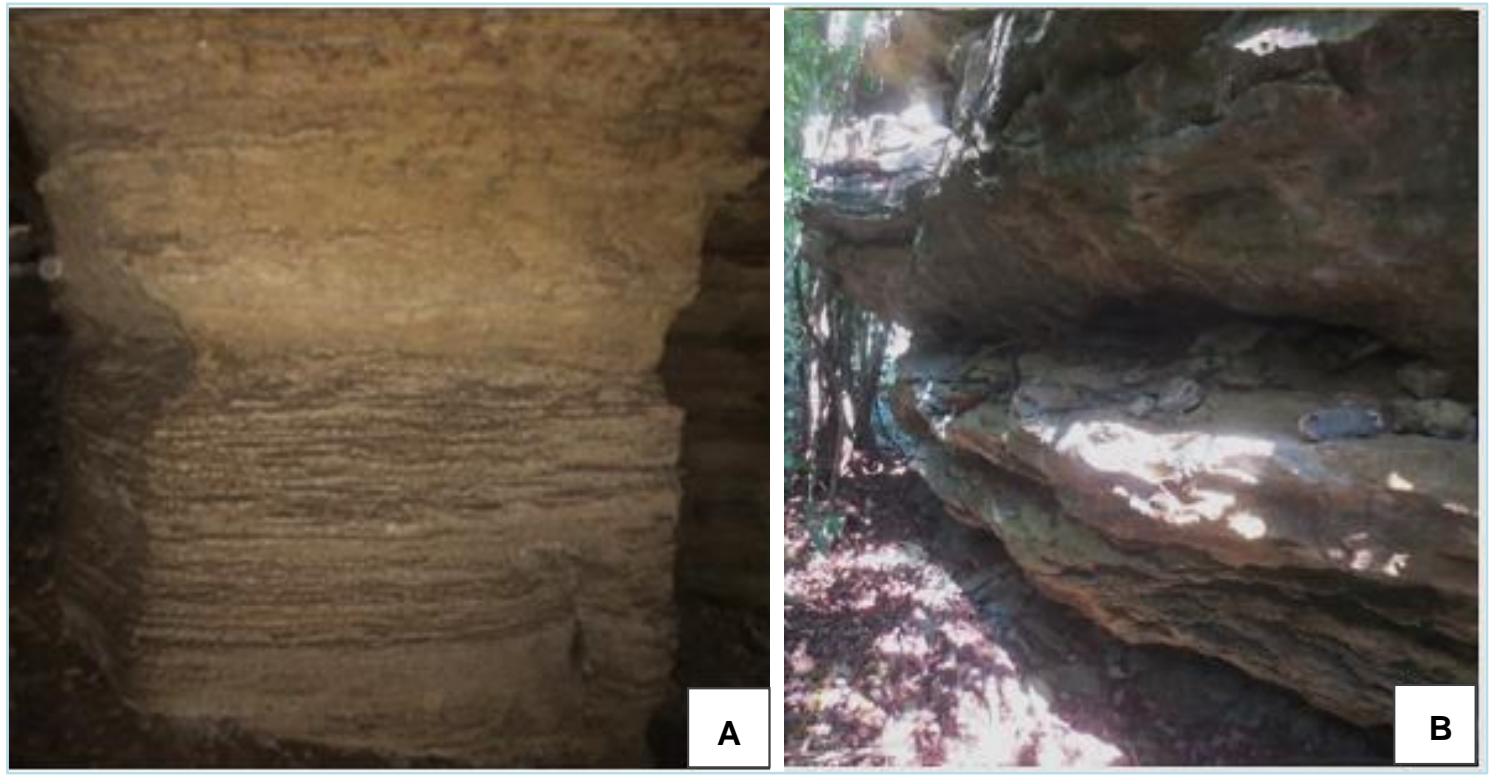

Fig. 7. A. Stratigraphic sequence of the limestone massif of Cheringoma Formation. B. Differential weathering of the massif strata.

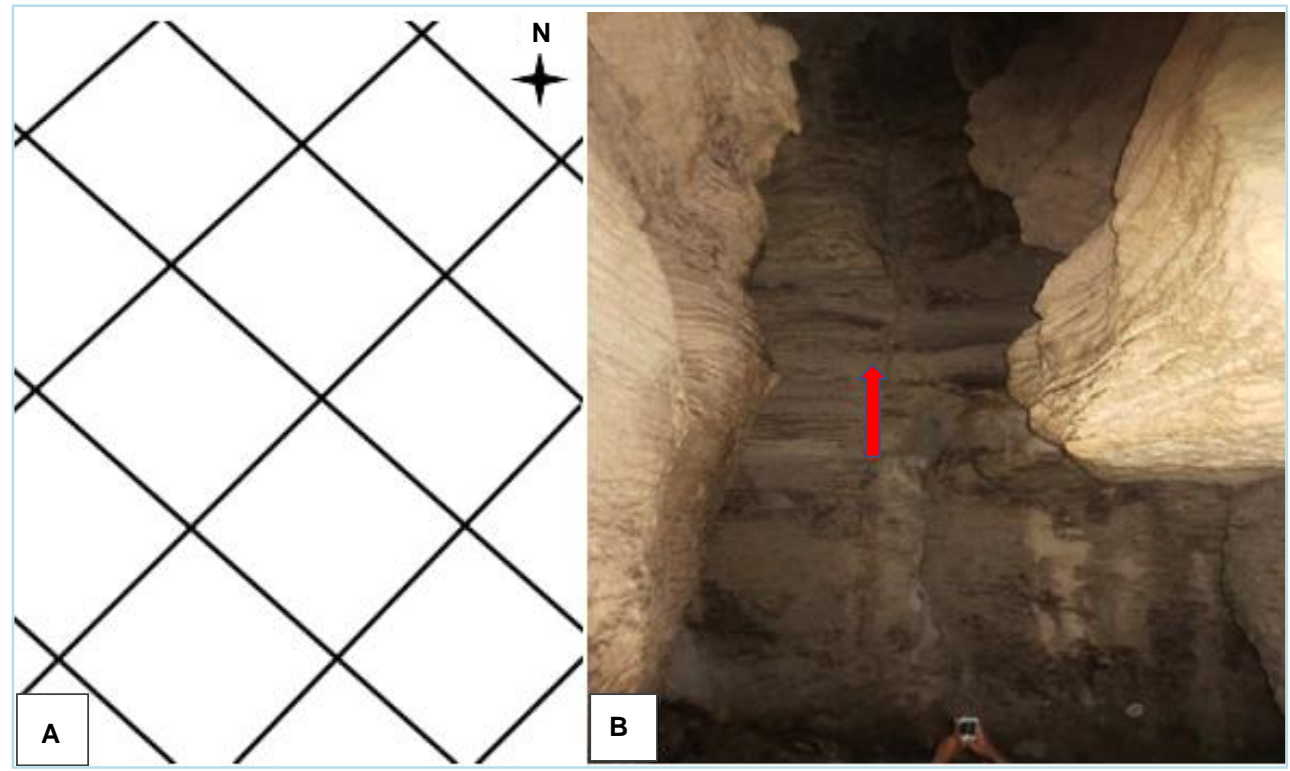

Fig. 8. A. Idealization of the orientation of two fracture families. B. Main fracture, in one of the cave walls.

According to Prelovsek (2012) dissolution and abrasion are the basic processes in cave formation. Given the visible heterogeneity in the Khózuè karst strata, it can also be inferred that dissolution and abrasion affect the deepest strata, which would be the most susceptible to weathering, and would have been the pioneers in the early conduit development (Figs. 9, 10), thus creating conditions for water circulation, and consequently further enhancing the weathering and erosion of the rock massif. Because caves are filled with water, dissolution occurs on surfaces, including floors, walls and ceilings (Press, 2006), which gradually favors the expansion of the conduits that make up the preferential groundwater flow routes (Karmann, 2000).

If at the bottom of the fracture a conduit arises, then the physical forces begin to act significantly on the upper strata which initiate rupturing through the anisotropic zones, shedding fragments that are easily weathered and eroded (Fig. $10 \mathrm{~A}$ ). The conduit related since the beginning to the guide fracture, is growing, reaching larger dimensions and forming caves (Karmann, 2000; Fig. 10B). 
As can be observed in the Khózuè caves, it is possible to understand in situ, and even to predict the occurrence of certain events just by analyzing the fractures and other structures. For example, Figure 10 documents the verticality of the walls, as well as the angularity of the block still fixed at the cave top. It also shows that the longitudinal growth of this cave section, besides being influenced by the guide fracture b (whose vertical continuity is still visible on the bottom wall and on the left side, indicated by the red arrows in Fig. 10), was also favored by other fractures of the same family (a and c). This block has any support at the base. In addition, your connection to the right wall (which also coincides with the fracture $\mathrm{c}$ - indicated by the blue arrow in Fig. 10) is already sufficiently opened. So, it can easily be
RESEARCH PAPER

inferred that in the near future, this huge block will be detached, contributing to the increase of the cave width in that section.

Taking into account this example, it can be supposed that the ruptures in the upper strata and the successive block detachments, gave rise in the past and continue to cause the growth of Khózuè caves, which were developed in a straight line and tended to conserve the vertical walls (Fig. 10). The detachments in the Khózuè caves are notorious for the piles of rock fragments, ranging from millimeter-sized lithoclasts to those that can reach tons of weight. Without disregarding the importance of dissolution, these amounts of rock material are enough to understand how much physical processes have contributed to Khózuè karst dynamics.
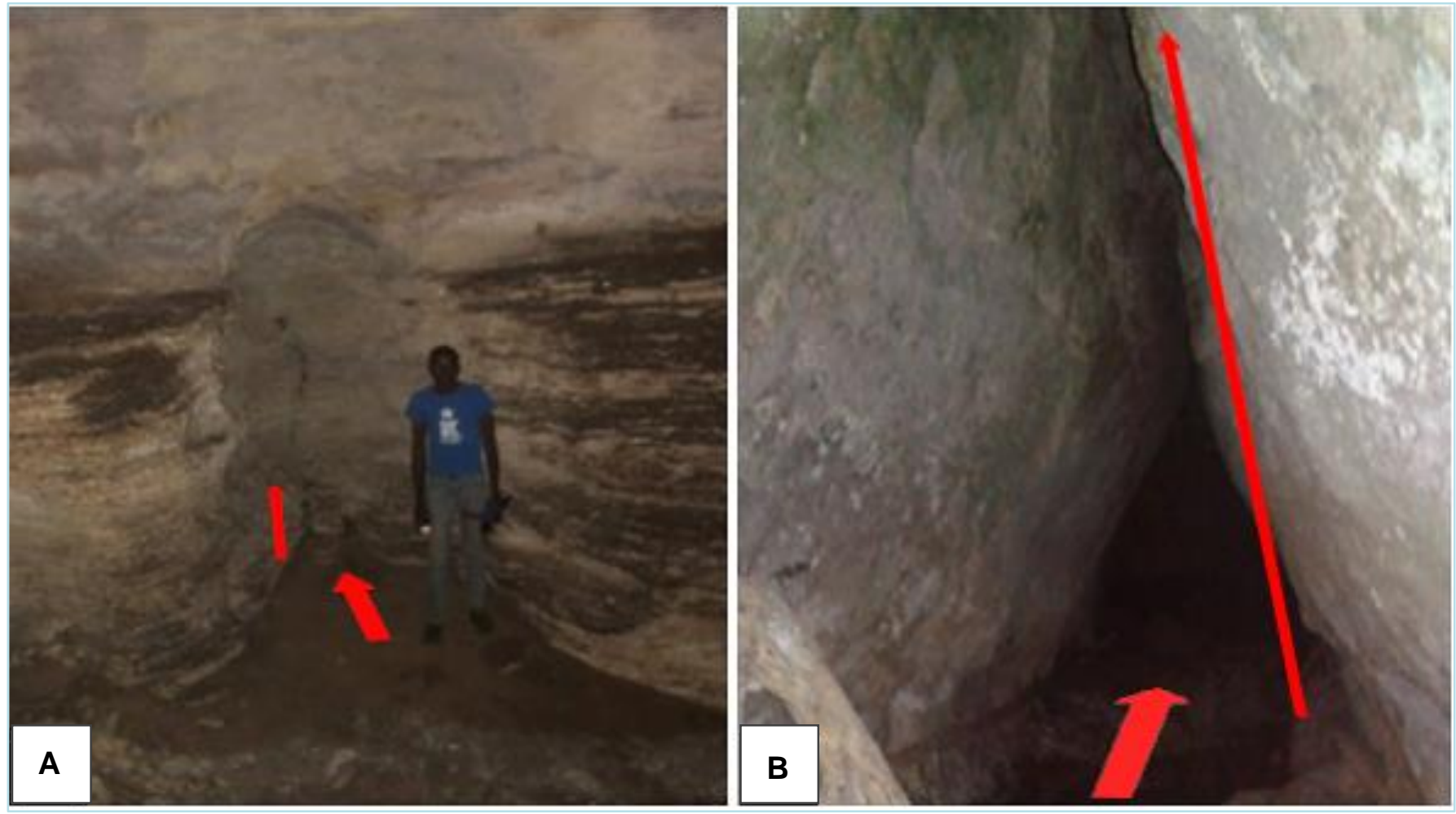

Fig. 9. A. A fracture initiating a cavity. B. Cavity growth following the fracture, reaching cave dimensions.

\subsection{Dolines evolution}

In Khózuè there are also dolines which can be considered as the fundamental form of karst relief in this region. Dolines are originated from infiltration at points of intersection of the diaclasses/fractures, where soluble particles are detached or removed from the rock, providing a slow lowering of the entire area from the center of the fractures, thus giving rise to a circular depression (e.g., Valois 2011; Fernández, 2012; Waltham, and Lowe, 2013). In some places, dissolution can so thin the ceiling of a limestone cave that it suddenly collapses, producing a doline (Press, 2006). Similar to what has been explained in relation to the caves, the formation of Khózuè dolines is also influenced by the intersection of guide fractures (which can be seen in the caves ceiling; Fig. 11A).

In Khózuè, the intersection of fractures not only defines the place but also outlines the doline morphology that is forming. It is possible to deduce that if fractures intersect at certain points, over time caves also intersect at the same points.

Khózuè dolines are associated with an advanced phase of cave development. The end result of successive strata ruptures of the cave ceiling is the emergence of collapsing dolines at the intersections of the caves (which were in the past only fracture intersections).

In Khózuè there are dolines with peculiar morphologies, for instance with angular sinuosity, due to the emergence of 
early dolines or even assuming an unusual cross morphology, preserving the orientation of the fractures related to their origin.
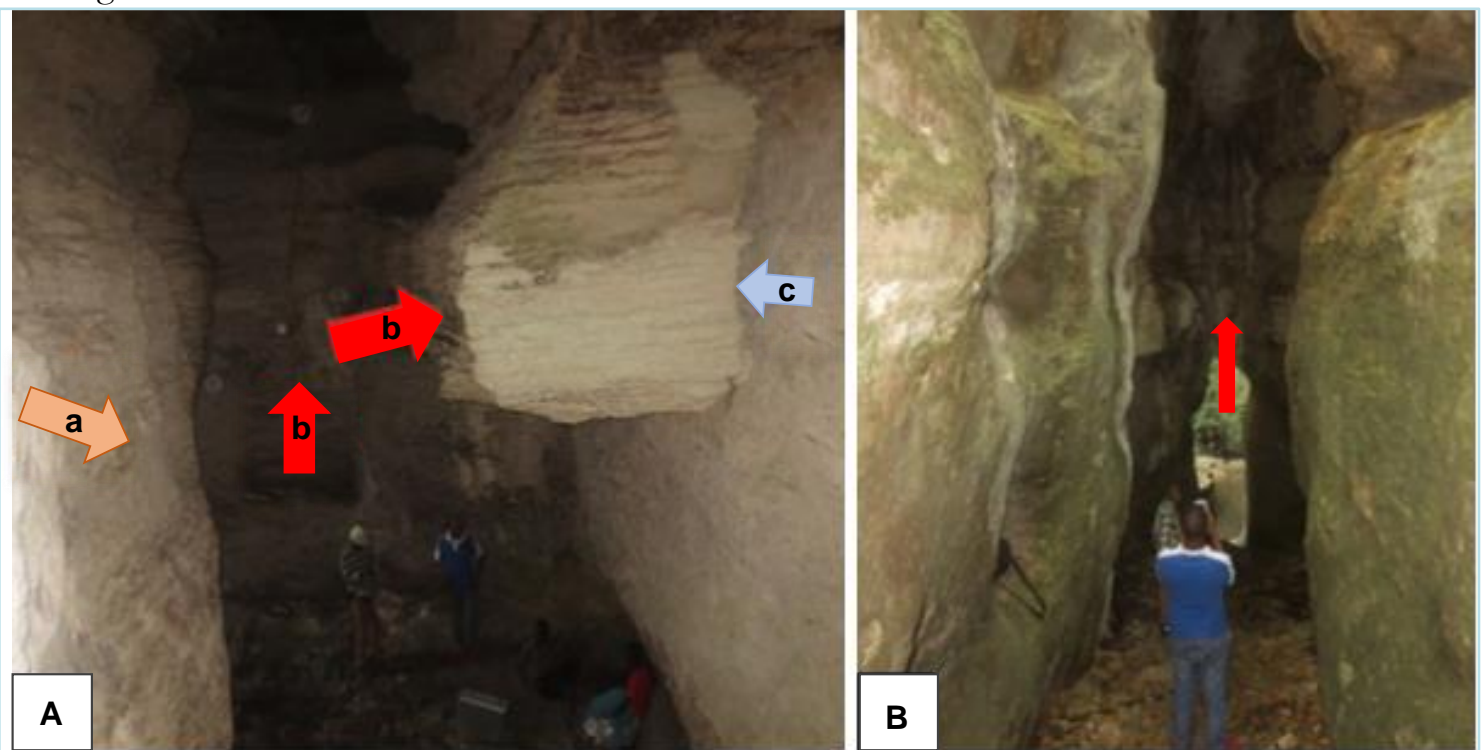

Fig. 10. A. Block fixed to the cave wall, and on the verge of falling. B. Cave orientation following the fractures.
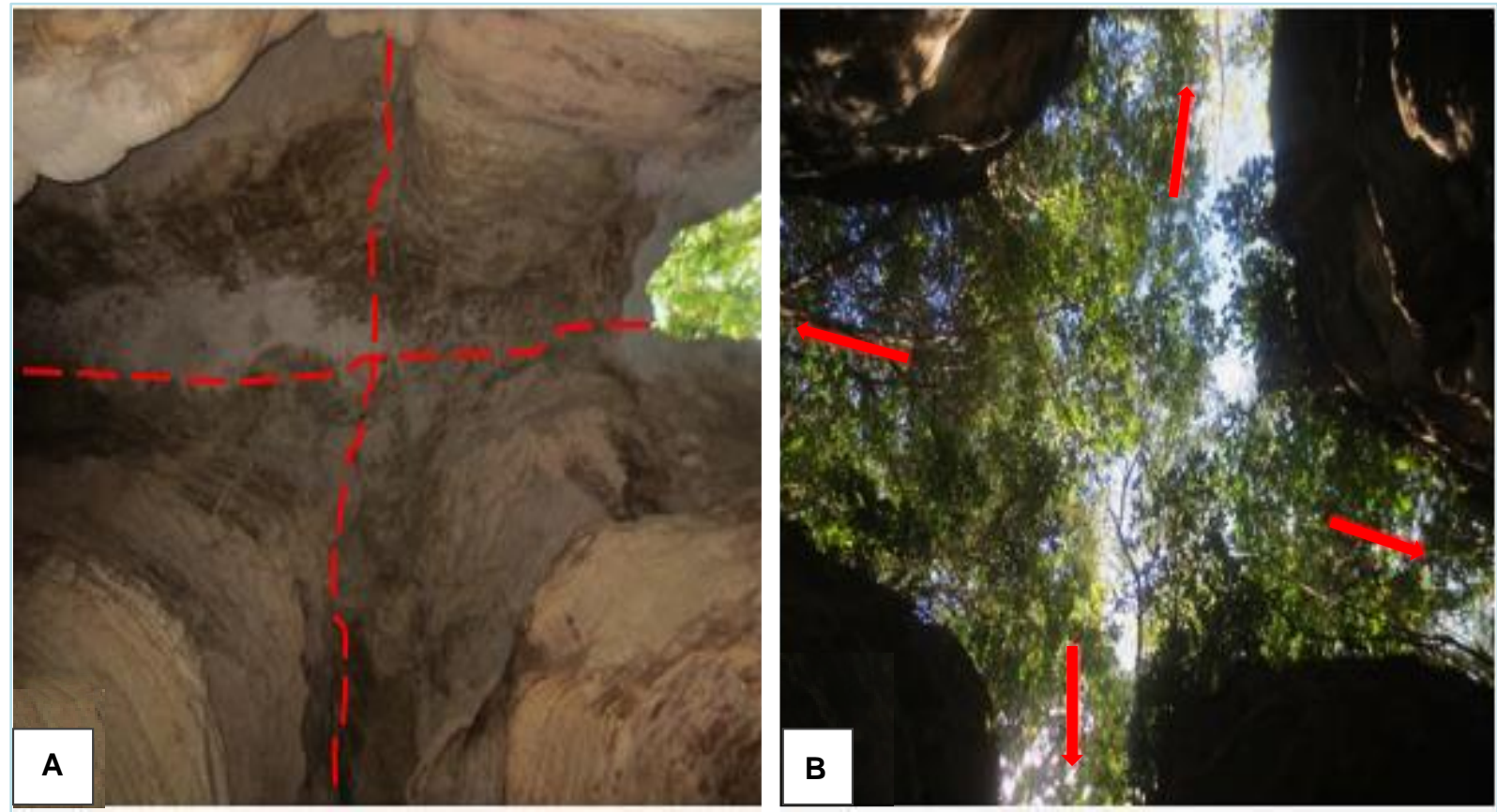

Fig. 11. A. The intersection of fractures in the cave. B. Doline with cross form.

\subsection{Caves end}

The successive widening of the underground cavities generates imbalance and instability in the massif, causing the rupture of the cavity ceiling (De Vallejo et al., 2002). In Khózuè can be observed that the ceiling last collapse is the begin of the cavity disappearing, or when the ceiling collapses, stay the walls. These walls and old ceilings are delivered to the agents of external geodynamics and are 
processes that are affecting the present caves. Currently there are only traces of its past existence.

For their compositional contents, the limestones differ from each other and, consequently, exhibit different physicochemical behaviors. The limestone of Cheringoma Formation has a good development of caves. However, we cannot expect that the neighboring Gruja Formation (GTK Consortium, 2006), with low fracturing, will form cavities of similar size and morphology to that found in Khózuè. On the other hand, the limestone of the Jofane Formation, Limestone Member of Urongas (GTK Consortium. 2006), also does not have adequate conditions for the development of large underground cavities due to the noticeable excessive fracturing which will favor the collapse of the cavities ceiling.

\section{Final Considerations}

This study revealed that the Khózuè caves grow in length and height, with orientations well defined by guide fractures, generated by the intense tectonic activity in the region, such as related to the development of the East African Rift System. Considering the verticality of the walls and recognizing the weakness of the stratification plans at some levels, it can be concluded that, although dissolution has played a key role since its formation, the Khózuè caves are collapsing.

Conditioned by fracturing, the ceiling collapsing and the abatement conditions (small abatements), both Khózuè caves and dolines tend to assume morphology as a function of the main fractures related to their origin and culminating in the formation of dolines with very winding morphology, even cross-shaped. In the Khózuè caves many structures can be identified, but not all repeat much, such as the speleothems. This characteristic is also common to stalagmites and columns and is an interest issue to be studied.

The confluence of several natural phenomena, especially those related to external geodynamics, was over time, transforming Khózuè limestone massifs into a karst with specific characteristics. At present, the same external conditions continue to act and transform this massif into a potential geosite, where morphological and landscape aspects present a peculiar identity that can make Khózuè an ideal place for ecotourism.

\section{References}

Afonso, R.S, Marques, J.M., Ferrara, M., 1998. A evolução geológica de Moçambique. Uma síntese, Lisboa, Portugal.

Afonso, R.S., 1977. Geologia da área da GorongosaInhaminga. Notícia Explicatíva da folha Sul-E36-Q (1934). Imprensa Nacional de Moçambique, Maputo, Moçambique.
RESEARCH PAPER

Arnott, H.J., Pautard, F.G.E., 1970. Calcification in Plants. In: Schraer H. (eds) Biological Calcification: Cellular and Molecular Aspects. Springer, Boston, MA. https://doi.org/10.1007/978-1-4684-8485-4_8

Audra, P., Palmer, A.N., 2011. The pattern of caves: controls of epigenic speleogenesis. Géomorphologie: relief, processus, environnement, 17, 359-378. https://doi.org/10.4000/geomorphologie.9571

Barros-Galvis, N., Villaseñor, P., Samaniego, F., 2015. Analytical Modeling and Contradictions in Limestone Reservoirs: Breccias, Vugs, and Fractures," Journal of Petroleum Engineering, vol. 2015, Article ID 895786, 28 pages, 2015. https://doi.org/10.1155/2015/895786.

Batiot, C., Liñán, C., Andreo B., Emblanch C., Carrasco F., Blavoux B., 2003. Use of Total Organic Carbon (TOC) as tracer of diffuse infiltration in a dolomitic karstic system: the Nerja Cave (Andalusia, southern Spain). Geophysical Research Letters, 30. Online ISSN: 1944-8007

Benavente, J., Vadillo, I., Liñán, C., del Rosal, Y., Carrasco, F., 2015. Influence of the ventilation of a karst show cave on the surrounding vadose CO2 reservoir (Nerja, South Spain). Environmental Earth Sciense 74, 7731-7740.

Bleam, W.F., 2012. Acid-Base Chemistry. In: Soil and Environmental Chemistry. Academic Press, 496 p. https://doi.org/10.1016/C2011-0-05612-0

Boaz, N., Ciochon, R.L., 2001. The scavenging of "Peking Man”. Natural History, 110, 46-51

Bogli, A, 1980. Karst hydrology and physical speleology. Springer-Verlag, Berlin, 284 p.

Chorowicz, J., 2005. The East African rift system. Journal of African Earth Sciences 43, 379-410.

De Vallejo, L.I.G., Ferrer, M., Ortuño, L., Oteo, C., 2002. Ingeniería Geológica. Madrid, Pearson Educación.

DNG, 2006. Geological Map, scale 1:250,000. Worldbank Project on Institutional Capacity Building. National Directorate of Geology, Maputo, Mozambique.

DNG, 1968. Provisional Geological Map, Scale 1:250,000 and Map Explanation. National Directorate of Geology, Maputo, Mozambique.

Dreybrodt, W., 1988. Processes in Karst Systems. Berlin, Heidelberg: Springer-Verlag, 288 pp.

Fernández, C.M., 2012. Hidrogeología aplicada con aspectos ambientales, Editorial Digital Universitária Moa, Cuba.

Ford, D.C., Williams, P., 2007. Karst Hydrogeology and Geomorphology. John Wiley and Sons Ltd. ISBN 978-0470-84996-5

Gabrovšek, F., Stepišnik, U., 2011. On the formation of collapse dolines: A modelling perspective. Geomorphology $134 \quad$ (1-2), 23-31. https://doi.org/10.1016/j.geomorph.2011.06.007

Gams, I., Nicod, J., Sauro, M., Julian, E., Anthony, U., 1993, Environmental change and human impacts on the Mediterranean karst of France, Italy and the Dinaric Region, in Williams, P. W., ed., Karst terrains: 
environmental changes and human impacts: CremlingenDestedt, Catena Verlag, p. 59-98.

Gil, A.C., 2008. Métodos e técnicas de pesquisa social. 6.Ed. São Paulo, Atlas.

Gillieson, D.S., Smith, D.I., 1989, Resource management in limestone landscapes: international perspectives. In Proceedings of the International Geographical Union, Study Group Man's Impact on Karst, Sydney, p. 260.

Goldie, H.S., 1993, Human impact on karst in the British Isles. In: Williams, P. W. (Ed.), Karst terrains: environmental changes and human impact: CremlingenDestedt, Catena Verlag, p. 161-186.

Grün, R., Huang, P-H., Wu, X., Stringer, C.B., Thorne, A.G., McCulloch, M., 1997. ESR analysis of teeth from the paleoanthropological site of Zhoukoudian, China. Journal of Human Evolution 32, 83-91.

GTK Consortium, 2006. Notícia Explicativa da Carta Geológica 1:250.000. Direcção Nacional de Geologia, Maputo.

Gümbel, C.W., 1870. Beiträge zur foraminiferenfauna der nordalpinen Eozängebilde oder der kressenberger Nummuliten Schisten. Abhandlungen der MatematischPhysikalischen Classe der Königlich Bayerischen Akademie der Wissenschaften 10, 581-720.

Gunn, J. (Ed.), 2004. Encyclopedia of Caves and Karst Science. Taylor and Francis Group, New York London. ISBN 0-203-48385-5

Habermann, J.M., Alberti, M., Aldeias, V., Alemseged, Z., Archer, W. Bamford, M., Biro, D., Braun, D.R., Capelli, C., Cunha, E., Silva, A,M., Ferreirada, M., Lüdecke, T., Madiquida, H, Martinez, F.I., Mathe, J., Negash, E., Paulo, L.M., Pinto, M., Carvalho, S., 2019. Gorongosa by the sea: First Miocene fossil sites from the Urema Rift, central Mozambique, and their coastal paleoenvironmental and paleoecological contexts. Palaeogeography, Palaeoclimatology, Palaeoecology, 514, 723-738.

Gabrovöek, F. (Ed.). 2002. Evolution of karst: from prekarst to cessation. Postojna, septembre 2002, Organisé par l'Institut de recherche du Karst de Postojna (IZRK), Slovénie, sous la responsabilité de Fr. Gabrovšek [compte-rendu].

Günay, G., Kenneth, J.S., Derek, F., Ivan, J.A.,Hüseyin, K., Akilli, Sinan, A., 2001. Present state and future trends of Karst studies: proceedings of the 6th International Symposium and Field Seminar, Marmaris, Turkey, 17-26 September 2000.

Haldar, S.K., Tišljar, J., 2014. Sedimentary Rocks. In: Introduction to Mineralogy and Petrology, Elsevier. https://doi.org/10.1016/C2012-0-03337-6 ISBN 978-012-408133-8

Huang, W., Ciochon, R., Gu, Y., Larick, R., Fang, Q., Schwarcz, H., Yonge, C, de Vos, C., Rink, W., 1995. Early
Homo and associated artefacts from Asia. Nature, 378, 275-78

Iliffe, J. E., Lerche I., DeBuyl, M., 1991. Basin analysis and hydrocarbon generation of the South Mozambique Graben using extensional models of heat flow. Marine and Petroleum Geology 8, 152-162.

Jennings, J.N., 1985. Karst Geomorphology. 2nd ed., Blackwell. ISBN 0-631-14032-8

Ji, H., Wang, S., Ouyang, Z., Zhang, S., Sun, C., Liu, X., Zhou, D., 2004. Geochemistry of red residua underlying dolomites in karst terrains of Yunnan-Guizhou Plateau I. The formation of the Pingba profile. Chemical Geology, 203, 1-27.

Karmann, I., 2000. Ciclo de água. In: Teixeira, W., Fairchild, T., Toledo, M.C.M., Taioli, F. (Orgs.), 2000. Decifrando a Terra. São Paulo: Cia. Editora Nacional.

Klein, C., Dutrow, B., 2012. Manual de Ciência dos Minerais. 23. Ed. Bookman.

Lamarck, J.B., 1801. Système des animaux sans vertèbres, ou tableau général des classes, des ordres et des genres de ces animaux, Présentant leurs caractères essentiels et leur distribution, d'apres la considération de leurs rapports naturels et de leur organisation, et suivant l'arrangement établi dans les galeries du Muséum d'Histoire Naturelle, parmi leurs dépouilles conservées, Précédé du discours d'ouverture du Cours de Zoologie, donné dans le Muséum National d'Histoire Naturelle l'an 8 de la République. Published by the author and Deterville, Paris: viii +432 pp. Available online at http://biodiversitylibrary.org/page/14117719

Läuchli, A., Grattan, S.R., 2012. Soil pH extremes. In: Shabala, S. (Ed.), Plant Stress Physiology, CCAB International, pp. 194-209.

Leymerie, A., 1846. Mémoire sur le terrain à Nummulites (épicrétacé) des Corbières et de la Montagne Noire. Mémoires de la Société Géologique de France (2) 1, 337 372, pls. 12-17. Available online at https://www.biodiversitylibrary.org/page/42315000

Maldonado, V., Monteiro, L.G.P., Rotti, A., Pereira, C., Araújo-Júnior, H.I., Leonardo dos Santos Avilla, L.S., 2016. Taphonomic aspects of deer (Mammalia, Cetartiodactyla, Cervidae) remains from a Quaternary cave deposit in Northern Brazil. Journal of Sedimentary Environments, 1(2), 228-241. https://doi.org/10.12957/jse.2016.23026

Lakatos, E.M., Marconi, M.A., 2003. Fundamentos de metodologia científica. 5. ${ }^{a}$ Ed. São Paulo, Editora Atlas, 2003.

Mashaba, V., Altermann, W., 2015. Calculation of water saturation in low resistivity gas reservoirs and pay-zones of the Cretaceous Grudja Formation, onshore Mozambique basin. Marine and Petroleum Geology 67, 249-261

Ministério da Administração Estatal, 2014. Perfil do Distrito de Cheringoma, Província De Sofala. Edição 2014. 
Available online at http://www.maefp.gov.mz/wpcontent/uploads/2017/04/Cheringoma.pdf

Mueller, C.O., Wilfried Jokat, W., Schreckenberger, B., 2016. The crustal structure of Beira High, central Mozambique - Combined investigation of wide-angle seismic and potential field data. Tectonophysics, 683, 233-254.

Mueller, O.C., Jokat, W., 2017. Geophysical evidence for the crustal variation and distribution of magmatism along the central coast of Mozambique. Tectonophysics, 712-713, 684-703.

Müller, O.F., 1776. Zoologiæ Danicæ Prodromus, seu Animalium Daniæ et Norvegiæ indigenarum characteres, nomina, et synonyma imprimis popularium. Havnix [Copenhagen]: Hallageri. xxxii +274 pp. Available online at http://www.biodiversitylibrary.org/item/47550

Nairn, A.E.M., Lerche, I., Iliffe, J.E., 1991. Geology, basin analysis and hydrocarbon potential of Mozambique and the Mozambique. Earth-Science Reviews 30, 81-124.

Norton, S.A., Veselý, J., 2003. Environmental Geochemistry: Neutralization of Episodic and Longerterm Acidity. In: Holland H.D., Turekian, K.K. (Eds.), Treatise on Geochemistry. Copyright (C) 2003 Elsevier Ltd. ISBN 978-0-08-043751-4

Ojeda, L., Vadillo, I., Etiope, G., Benavente, J., Liñán, C., del Rosal, Y., Tapia, S.T., Moríñigo, M.A., Carrasco, F., 2019. Methane sources and sinks in karst systems: The Nerja cave and its vadose environment (Spain). Geochimica et Cosmochimica Acta 259, 302-315.

Palmer, A.N., 2009. Cave Geology. $2^{\text {nd }}$ Printing, Cave Books. ISBN 978-0-939748-66-2

Pereira, Z., Fernandes, P., Lopes, G., Marques, J., Vasconcelos, L., 2016. The Permian-Triassic transition in the Moatize-Minjova Basin, Karoo Supergroup, Mozambique: A palynological perspective. Review of Palaeobotany and Palynology 226, 1-19.

Philippi, R.A., 1837. Beweis, dass die Nulliporen Pflanzen sind. Archiv für Naturgeschichte 3, 387-393, figs 2-6, pl. IX.

Prelovsek, M., 2012. the dynamics of the present-day speleogenetic processes in the stream caves of Slovenia. Publisher: ZRC Publishing. ISBN: 978-961-254-405-8

Press, F., Raymond, S., Grotzinger, Jordan, J., Thomas, H., 2006. Para Entender A Terra. $4^{a} e d$, Porto Alegre, Bookman.

Riding, R., 2000. Microbial carbonates: the geological record of calcified bacterial-algal mats and biofilms. Sedimentology 47, 179-214.

Said, A., Moder, C., Clark, S., Ghorbal, B., 2015. CretaceousCenozoic sedimentary budgets of the Southern Mozambique Basin: Implications for uplift history of the South African Plateau. Journal of African Earth Sciences, 109, 1-10.
Salman, G., Abdula, I., 1995. Development of the Mozambique and Ruvuma sedimentary basins, offshore Mozambique. Sedimentary Geology 96, 7-41.

Schlüter, T., 2006. Geological Atlas of Africa. SpringerVerlag Berlin, Heidelberg. ISBN 10, 3-540-29144-x

Steinbruch, F., 2010. Geology and geomorphology of the Urema Graben with emphasis on the evolution of Lake Urema. Journal of African Earth Sciences 58, 272-284.

Stoliczka, F., 1867-1871. Cretaceous fauna of southern India. Palaeontologia Indica, being figures and descriptions of the organic remains procured during the progress of the Geological Survey of India. Memoirs of the Geological Survey of India. 5. Published in parts.

Stringer, C.B., Howell, F.C., Melentis, J.K., 1979. The Significance of the Fossil Hominid Skull from Petralona, Greece. Journal of Archaeological Science 6, 235-253.

Su, C., Tan, X., Shi, K., Zou, J., Lu, F., Luo, S., Tang, H., Zhang, X., 2017. Characteristics and significance of the penecontemporaneous karst in lacustrine carbonate, Da'anzhai Member, Lower Jurassic, Beibei area, eastern Sichuan Basin. Petroleum 3 (3), 292-300. https://doi.org/10.1016/j.petlm.2016.12.006

Summerfield, M.A., 1991. Global geomorphology, an introduction to the study of landforms. New York: John Wiley \& Sons, $537 \mathrm{pp}$.

Sweeting, M.M., 1973. Karst Landforms, Macmillan. ISBN 0-231-03623-X

Toledo, M.C.M., Oliveira, S.M.B., Melfi, A.J., 2000. Intemperismo e formação do solo. In: Teixeira, W., Fairchild, T., Toledo, M.C.M., Taioli, F. (Orgs.), 2000. Decifrando a Terra. São Paulo: Cia. Editora Nacional.

Trudgill, S.T., 1985. Limestone Geomorphology. London and New York: Longman, 196 pp.

Urich, P.B., 2002. Land use in karst terrain: review of impacts of primary activities on temperate karst ecosystems. Science for Conservation 198, Published by Department of Conservation, Wellington, New Zealand. Valois, R., 2011. Caractérisation structurale de morphologies karstiques superficielles et suivi temporel de l'infiltration à l'aide des méthodes électriques et sismiques. Géophysique [physics.geo-ph]. Université, Pierre et Marie Curie - Paris VI, 2011. Français.

van Beynen, P. (Ed.), 2011. Karst Management. Springer. ISBN 978-94-007-1206-5

Vermeulen, J.J., Whitten, T., 1999. Biodiversity and Cultural Property in the Management of Limestone Resources in East Asia: Lessons from East Asia. The World Bank, ISBN 978-0-821345-08-5

Waltham, T., Lowe, D. (Eds.), 2013. Caves and Karst of the Yorkshire Dales. British Cave Research Association. Buxton, 255 p. https://doi.org/10.1002/gj.2524

Zhang, D., Zhang, Y., Zhu, A., Cheng, X., 2001. Physical mechanisms of river waterfall tufa (travertine) formation. Journal of Sedimentary Research, 71, pp. 205-216. 